\title{
Cutaneous Melanoma pT1a TNM Finding v8
}

National Cancer Institute

\section{Source}

National Cancer Institute. Cutaneous Melanoma pT 1a TNM Finding v8. NCI Thesaurus.

Code C136942.

Cutaneous melanoma measuring less than $0.8 \mathrm{~mm}$ in thickness. Ulceration status:

Without ulceration. (from AJCC 8th Ed.) 